\title{
Evaluation of some plant extracts for controlling mycoflora causing spoilage of stored cereals and legumes
}

\author{
Zakaria A. M. Baka*, Mamdouh S. Serag, Tarek A. Kardosha \\ Botany Department, Faculty of Science, Damietta University, Damietta, Egypt
}

Received: 08 December 2013 / Accepted: 05 February 2014

* Corresponding author: (Fax: +20.57.2403868, email: zakariabaka@du.edu.eg)

\begin{abstract}
This study aimed to isolate and identify seed-borne fungi associated with some cereals and legumes and the possibility of their control by some plant extracts. The studied cereals and legumes were Sorghum bicolor, Triticum aestivum, Oryza sativa, Lens esculentus, Vigna sinensis, Arachis hypogea and Vicia faba. Thirteen fungal species were isolated from these cereals and legumes. Five fresh plants called Allium sativum, Aloe vera, Mentha basilicum, Musa acuminate and Eucalptus rostrata and eleven dried plants called Datura stramonium, Zingiber officinale, Azadirachta indica, Jatropha curcas, Euphorbia peplis, Ocimum basilicum, Carum carvi, Rosmarinus officinalis, Nigella sativa, Cuminum cyminum and Citrullus colocynthis as medicinal plants were screened for their antifungal activities. Aqueous extracts of all mentioned plants were tested against Aspergillus niger, A. flavus and Penicillium chrysogenum in vitro because they represented the highest percentage of occurrence on seeds and grains. Allium sativum and Zingiber officinale exhibited maximum antifungal activity, whereas Datura stramonium and Citrullus colocynthis showed moderate activity. In addition, these plant extracts were tested against the germination of seeds and grains by using blotter plate method. Treated seeds and grains by plant extracts showed an increase of their germination (\%) and reduction of seed-borne fungal infection.
\end{abstract}

Keywords: Antifungal activity, Cereals, Legumes, Medicinal plants, Seed-borne mycoflora

\section{Introduction}

Legumes (Fabaceae) are one of the most important plant families all over the world. It is used for human feeding, animals, poultry and other consumption. Legumes are the second after grasses (cereals) in providing food crops for world agriculture [1]. In comparison to cereal grains, the seeds of legumes are rich in high quality protein, providing man with a highly nutritious food resource [2].

Cereal grains have been the principal component of human diet for thousands of years and have played a major role in shaping human civilization. Around the world, rice, wheat, and maize, and to a lesser extent, are important 
staples critical to daily survival of billions of people. More than $50 \%$ of world daily caloric intake is derived directly from cereal grain consumption [3].

Seed-borne fungi have been found to affect the growth and productivity of crop plants including legumes and cereals $[4,5]$. Presence or absence of seed-borne fungi on seed surface is one of the important aspects that determine the quality of seeds and grains. Attempts have been made to reduce seed-borne fungi by chemical treatment of the seeds and some successes have been reported. Seed dressings are used to eliminate most surface infestation of seeds but have relatively little effect on internally borne organisms [6]. However, the application of these fungicides may not always be desirable, owing to their toxic effects on non-target organisms [7].

An urgent need for alternatives to fungicides for the control of seed-borne fungi are important In recent years, much attention has been given to nonchemical systems for seed treatment to protect them against seed-borne pathogens. Plant extracts have played a significant role in the inhibition of seed-borne pathogens and in the improvement of seed quality and field emergence of plant seeds. Many authors reported the effective and safe use of plant extracts for controlling seed-borne fungi [8-11]. However, in this study, the effects of water extracts of some plants on seed-borne fungi of some legumes and cereals; and on seed germination were investigated.

\section{Materials and methods}

\section{Collection of legumes and cereals}

Some stored cereals and legumes of economically important crops were collected from some markets in Damietta Governorate, Egypt such as sorghum (Sorghum bicolor), wheat (Triticum aestivum), rice (Oryza sativa), lentil (Lens esculentus), cowpea (Vigna sinensis), peanut (Arachis hypogea) and faba bean (Vicia faba).

\section{Isolation and identification of Fungi}

Fungal isolation from collected samples was carried out by using direct plating method. First, grains and seeds were surface sterilized using $2.5 \%$ sodium hypochlorite for $1 \mathrm{~min}$ and rinsed with distilled water and dried between sterile
Whatman No. 1 filter papers. Then, five grains or seeds spaced out in the Petri dishes containing PDA medium $(200 \mathrm{~g}$ potato $+20 \mathrm{~g}$ glucose +20 $\mathrm{g}$ agar in liter distilled water). An antibacterial agent chloramphenicol $(50 \mathrm{ppm})$ was used to inhibit the growth of bacteria. The Petri dishes were incubated at $27 \pm 2{ }^{\circ} \mathrm{C}$ for 5-7 days and examined daily for fungal growth [12]. The observed fungal colonies were sub-cultured to get pure culture. All isolates were identified according to their microscopic and macroscopic characteristics according to some authors [1319].

\section{Preparation of plant extracts}

For dried samples, the plant materials were airdried under the shade at $25-29^{\circ} \mathrm{C}$ until they became dry and crispy. Dried parts of the plants (Table 1) were ground using a blender and sieved to remove coarse particles. Ten grams from each fine powdered plant material was placed in a 250 $\mathrm{ml}$ beaker and extracted with $25 \mathrm{ml}$ of distilled water for $48 \mathrm{hr}$. Mixture was vigorously stirred for $5 \mathrm{~min}$. three times per day to prevent decay of water extracts. For fresh samples, water extract of fresh samples were prepared as follow: ten grams of each plant material were cut into small pieces using a sharp knife. The cutting plant material was mixed with $25 \mathrm{ml}$ of distilled water by using electrical blender. The homogenate was placed in a closed container and was left for 48 hr. [20].

\section{Assay of antifungal activity}

The antifungal activity assay was carried out by the standard method according to Gurgel et al. [21]. Potato dextrose agar media were sterilized by autoclaving at $121^{\circ} \mathrm{C}$ for $15 \mathrm{~min}$ and cooled to $45^{\circ} \mathrm{C}$. Then, about $20 \mathrm{ml}$ of PDA medium was poured into Petri dishes and allowed to solidify. Plant extracts were tested against Penicillium chrysogenum, Aspergillus niger and A. flavus because they exhibited the highest percentage of occurrence on seeds and grains. The fungus was spread over the media by using sterile cotton swab. Five-mm diameter of sterile filter paper (Whatman No.3) discs previously soaked in aqueous plant extract (400 and $500 \mathrm{mg} \mathrm{l}^{-1}$ ) were placed on the surface of the plates. The plates were incubated at $28^{\circ} \mathrm{C}$ for $48-72 \mathrm{hr}$. The experiment was performed in triplicates to minimize the error ratio. At the end of incubation period, the inhibition zones around each disc 
were measured to an accuracy of $0.1 \mathrm{~mm}$ and the effect was calculated as a mean of triplicate tests to evaluate the antifungal activity.

Effect of plant extracts on incidence of fungi and seed germination

Three replicates of 25 seeds per Petri-dish for each of the treated seeds including the controls were plated using the Blotter method as recommended by Mathur and Kongsdal [22]. These gave a total of 75 seeds for each treatment. They were then incubated for 7-10 days and then examined for seed-borne fungi. Records on incidence of seed-borne fungi and germination of treated seeds were then taken.

\section{Statistical analysis}

Analysis of variance (ANOVA) was performed on all transformed data (i.e. using the arcs in percentage transformation) collected in respect of parameters studied on effects of plant extracts and separation of treatment means was done using the LSD at 5\% level of significance.

\section{Results}

Fungi isolated from grains and seeds

Results obtained in Table 1 showed that thirteen fungal species were isolated from different seeds and grains. Aspergillus niger, A. flavus and $P$. chrysogenum showed the highest percentage of occurrence.

Antifungal activity of plant extracts against fungal species

Warm water extracts of five fresh plant samples namely Garlic, Aloe, Peppermint, Banana and Camphor were tested against some fungal isolates (Aspergillus niger, A. flavus and $P$. chrysogenum), only Garlic bulb had the highest antifungal activity. It is worth to mention that the antifungal activity of Garlic extract varied from one fungal species to another. The diameter of inhibition zone for Aspergillus niger, A. flavus and $P$. chrysogenum were $22.83,12.50$ and 10.83 $\mathrm{mm}$ at $400 \mathrm{mg} \mathrm{ml}^{-1}$, while at $500 \mathrm{mg} \mathrm{ml}^{-1}$ they were $24.33,18.0$ and $13.17 \mathrm{~mm}$, respectively (Fig. 1).

Table 1. List of the isolated fungal species from grains and seeds.

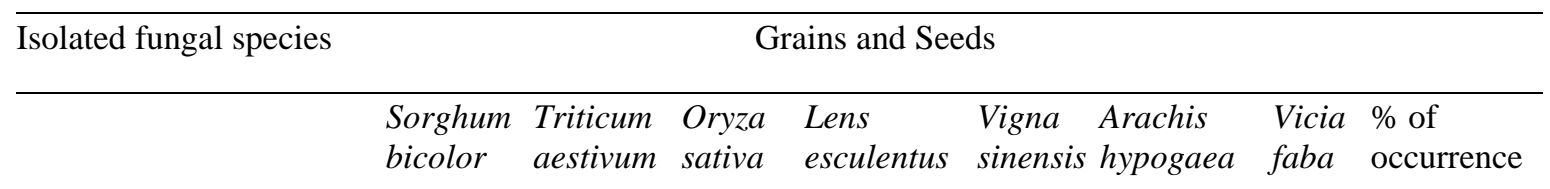

\begin{tabular}{|c|c|c|c|c|c|c|c|c|}
\hline Acremonium gramineum & - & 5.4 & - & - & - & - & - & 5.4 \\
\hline Alternaria alternata & 5.4 & - & - & - & - & - & - & 5.4 \\
\hline Aspergillus flavus & - & - & - & - & - & 8.1 & - & 8.1 \\
\hline Aspergillus niger & 2.7 & - & - & 2.7 & - & 2.7 & 2.7 & 10.8 \\
\hline Cladosporium herbarium & - & 2.7 & - & - & - & - & - & 2.7 \\
\hline Curvularia lunata & 2.7 & - & - & - & - & - & - & 2.7 \\
\hline Epicoccumn nigrum & - & - & 2.7 & - & - & - & 2.7 & 5.4 \\
\hline Fusarium moniliforme & 2.7 & - & - & - & 2.7 & - & - & 5.4 \\
\hline Mycelia sterilia & - & 2.7 & - & - & - & - & - & 2.7 \\
\hline Penicillium chrysogenum & 5.4 & 8.1 & 2.7 & 8.1 & 2.7 & 5.4 & 8.1 & 40.5 \\
\hline Rhizopus oryzae & - & - & - & 2.7 & - & - & 2.7 & 5.4 \\
\hline Rhizopus stolonifer & - & 2.7 & - & - & - & - & - & 2.7 \\
\hline Trichothecium roseum & - & - & 2.7 & - & - & - & - & 2.7 \\
\hline
\end{tabular}

- =absence

The antifungal activities of eleven dried plant water extracts (Datura, Ginger, Bitter apple, Jatropha, Basil, Neem, Caraway, Rosemary, Euphorbia, Black seeds and Cumin) were tested against the fungal species. Datura leaves extract exhibited the highest antifungal activity against all tested fungi except Aspergillus niger. The highest sensitive species to water extract of Datura leaves were Aspergillus flavus and Penicillium chrysogenum with inhibition zone of 12.50 and $12.33 \mathrm{~mm}$ at $400 \mathrm{mg} \mathrm{ml}^{-1}$, and 14.0 and 20.83 at $500 \mathrm{mg} \mathrm{ml}^{-1}$, respectively (Fig. 2). 
Water extract of dried powdered Ginger rhizome exhibited antifungal activity against all tested fungi with inhibition zone of 8.83, 8.167 and 8.0 $\mathrm{mm}$ at $400 \mathrm{mg} \mathrm{ml}^{-1}$, and 9.83, 11.67and 16.83 at $500 \mathrm{mg} \mathrm{ml}^{-1}$, respectively (Fig. 3). Water extract of dried bitter apple fruit showed antifungal activity against Penicillium chrysogenum only with inhibition zone of $22.83 \mathrm{~mm}$ at $500 \mathrm{mg} \mathrm{ml}^{-1}$ (Fig. 4).
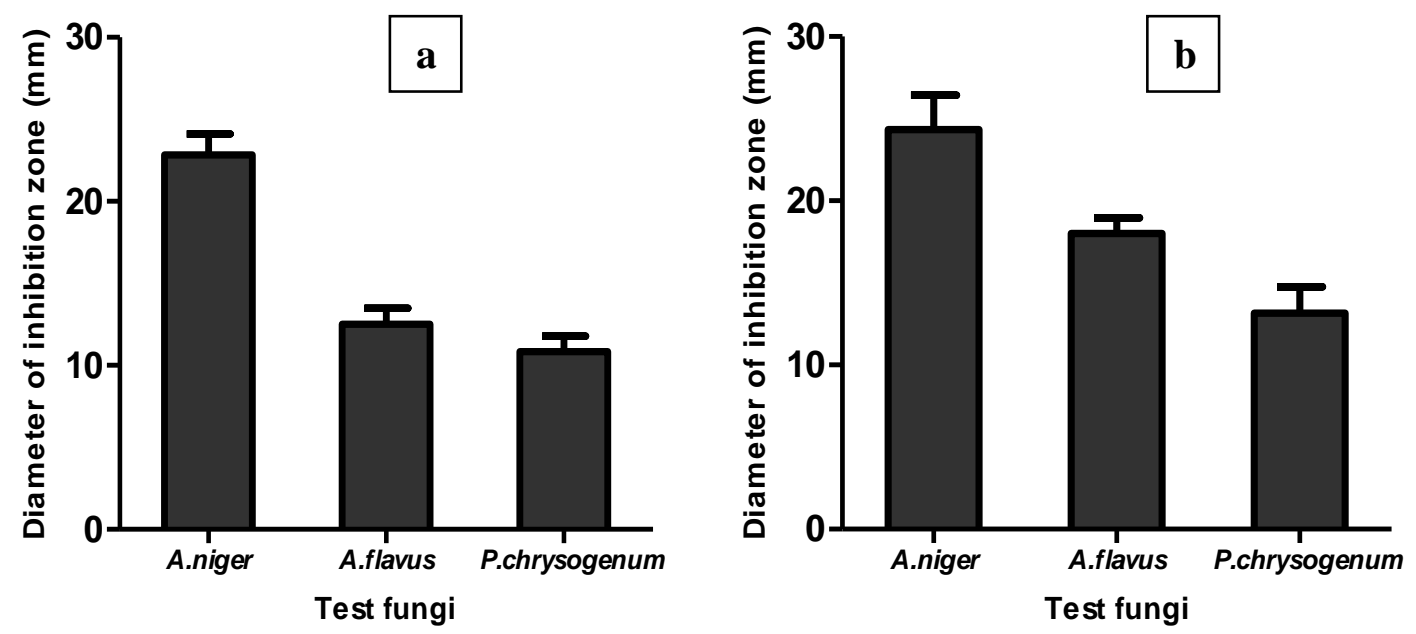

Fig. 1 Antifungal activity of fresh Allium sativum bulb water extract at $400 \mathrm{mg} \mathrm{ml}^{-1}$ (a) and $500 \mathrm{mg} \mathrm{ml}^{-1}$ (b) against fungal species.
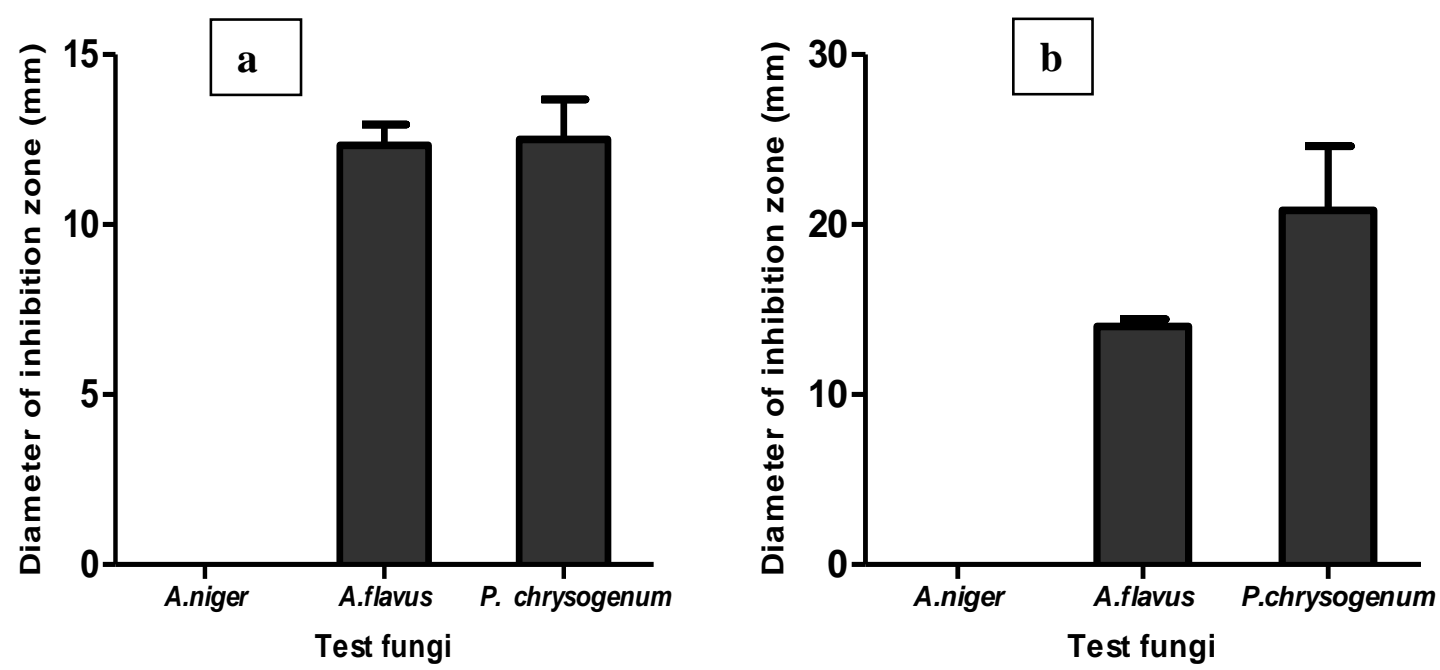

Fig. 2 Antifungal activity of dried Datura stramonium leaves water extracts at $400 \mathrm{mg} \mathrm{ml}^{-1}$ (a) and at $500 \mathrm{mg}$ $\mathrm{ml}^{-1}$ (b) against fungal species.

Effect of plant extracts on seeds and grains germination and fungal growth.

Results obtained in Table 2 showed the effect of different plant extracts on seeds and grains germination and fungal growth. In this experiment, four different plant extracts were used to controlling seed-borne fungi on seeds and grains which were Bitter apple, Ginger, Datura and Garlic. Sorghum grains treated with these extracts showed high seed germination with 93.3,
96.0, 97.3 and $94.7 \%$, respectively, while the untreated (control) grains showed $90.7 \%$. The fungal growth appeared only on grains treated with Bitter apple extract with $72.0 \%$, while the control was $96.0 \%$. Wheat grains treated with these extracts showed high grain germination with 88.0, 94.7, 92.0 and $93.3 \%$, respectively, while the control was $65.3 \%$. The fungal growth appeared only on the grains treated with Bitter apple extract with $34.7 \%$, while the control was $90.7 \%$. Rice grains treated with these extracts 
showed no germination. The fungal growth appeared only on grains treated with Bitter apple extract with $33.3 \%$, while the control seeds were $53.3 \%$.
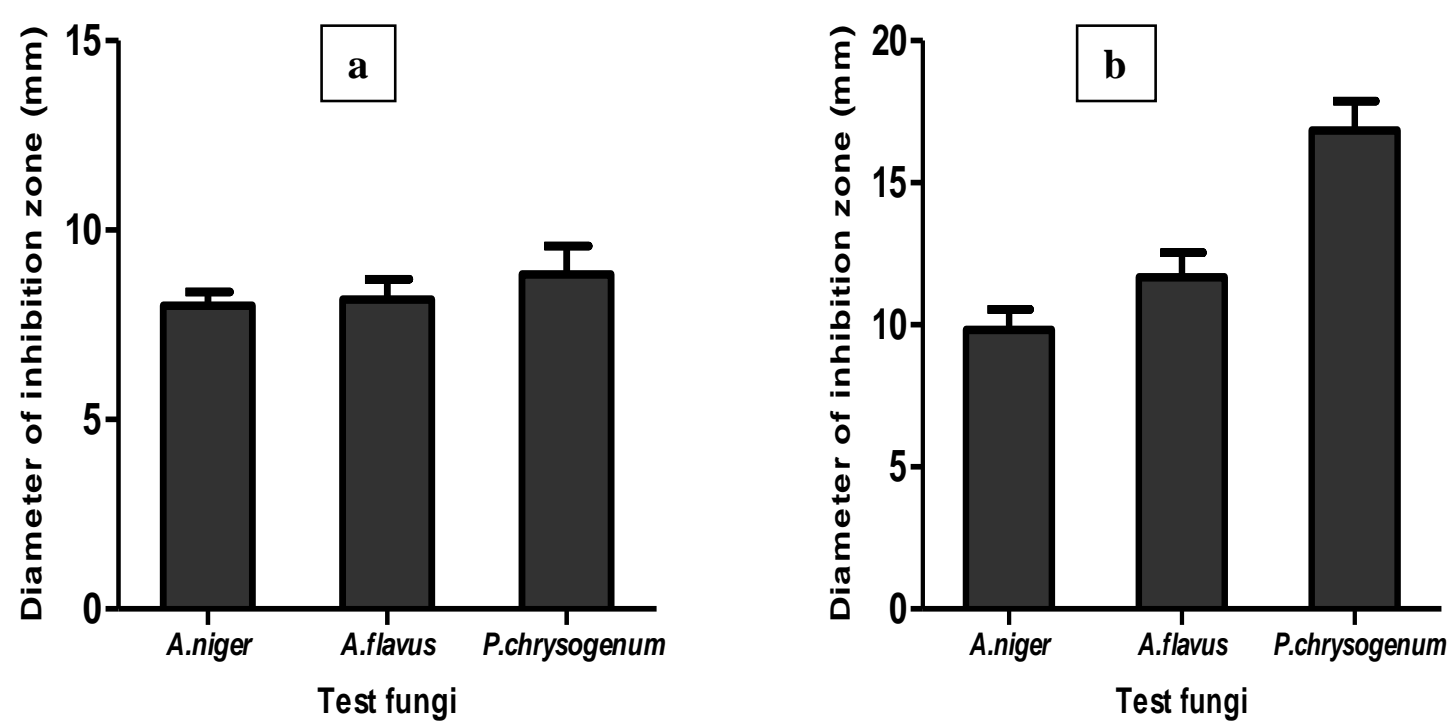

Fig. 3 Antifungal activity of dried Zingiber officinale powder extracts at $400 \mathrm{mg} \mathrm{ml}^{-1}$ (a) and at $500 \mathrm{mg} \mathrm{ml}^{-1}$ (b) against fungal species.

Lentil seeds treated with these extracts showed high seed germination with 80.0, 98.7, 96.0 and $98.7 \%$, respectively, while the control seeds were $73.3 \%$. The fungal growth appeared only on the seeds treated with bitter apple and Datura extracts with 26.7 and $53.0 \%$, respectively, while the control was $88.0 \%$. Cowpea seeds treated with these extracts showed high seed germination with 77.3, 93.3, 90.7 and $97.3 \%$, respectively, while the control was 60.0 $\%$. The fungal growth appeared only on the seeds treated with Bitter apple and Datura extracts with 17.3 and $8.0 \%$, respectively, while the control was $61.3 \%$. Faba been seeds treated with these extracts showed high seed germination with 78.7, 93.3, 90.7 and 98.7, respectively, while the control seeds was $77.3 \%$. The fungal growth appeared only on the seeds treated with Bitter apple extract with $48.1 \%$, while the control was $93.3 \%$.

\section{Discussion}

Seeds and grains play a vital role in the production of healthy crops. Healthy seeds and grains is the foundation of healthy plant; a necessary condition for good yields [23]. Many pathogenic fungi are seed transmitted, often reduce the germination ability or kill the infected plants or substantially reduce the productivity.
Therefore, control of seed-borne fungi is extremely important and the damaging effects can be relieved through integrated approaches [24].

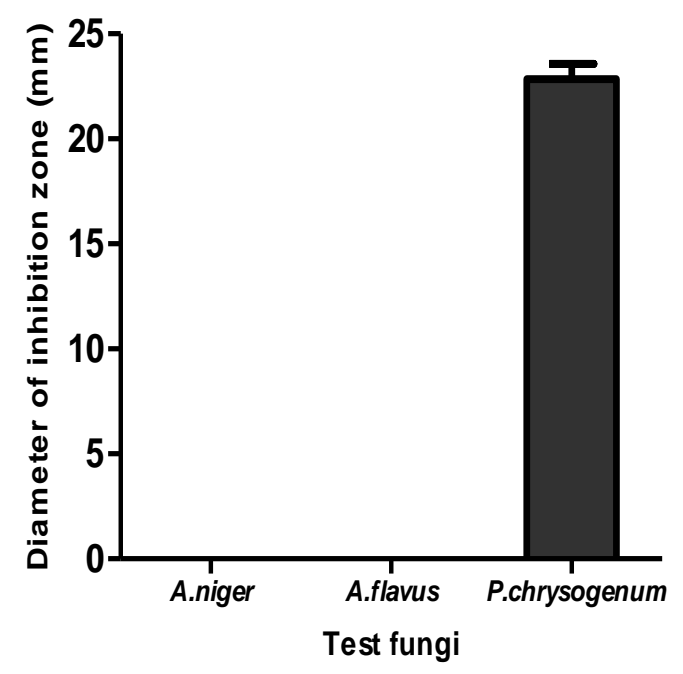

Fig. 4 Antifungal activity of water extracts of dried Citrullus colocynthis fruit at $500 \mathrm{mg} \mathrm{ml}^{-1}$ against fungal species.

Deteriorations by fungi are due to unhygienic conditions of storage and this in turn is associated with initial high moisture content of the stored products or absorption of moisture during storage due to defects in the storage system [25]. In the present study, the most 
common fungi isolated from seeds and grains were Aspergillus niger, A. flavus and Penicillium chrysogenum. These fungal species are very important for different reasons; they cause deteriorations in stored commodities [26-29], bring about reduction in the quality and quantity of agricultural products in storage and transit and also create health hazards in animals and human beings by producing toxic metabolites in the form of mycotoxins in the stored commodities [30,31]. Penicillium chrysogenum is a common fungus that can inhabit a wide variety of habitats [32].

From all samples extracted from fresh plants, only Garlic bulb exhibited the highest antifungal activity against isolated fungi. Lawson [33] reported that the most abundant sulfur compound in Garlic is allicin (S-allylcysteine sulfoxide), which is present at $10 \mathrm{mg} \mathrm{g}^{-1}$ fresh Garlic or 30 $\mathrm{mg} \mathrm{g}^{-1}$ dry weight. Various chemical constituents in garlic products, including non-sulfure compounds such as saponins, may contribute to the essential biological activities of garlic [34].

Datura leaves aquous extract possessed antifungal activity against all tested fungi except Aspergillus niger. Datura plants contain tropane alkaloid such as hyoscyamine, scopolamine and atropine but the seeds, leaves and the flowers contain the highest level of alkaloids. Besides its hallucinogen activity, Datura reported to have antimicrobial activity [35, 36]. Hussain et al. [37] reported that the leaf extract of Datura stramonium reduced the development of rust pustules on the leaves of wheat. The inhibitory effect of the plant extracts might be attributed to the presence of antifungal compounds. Water extract of ginger rhizome exhibited antifungal activity against all tested fungi. Ficker et al. [38] reported that gingerols and gingerdiol are the main antifungal principles presented in ginger rhizomes. Water extract of bitter apple fruit showed antifungal activity against Penicillium chrysogenum only. The antifungal effect of bitter apple attributed to the presence of the active compounds colocynthidin and colocynthin alkaloids which may be disrupt cytoplasmic membrane of the microorganisms through their action on lipids and protein [39].The present results indicated that the treated seeds and grains with plant extracts gave very good effects on their germination and also reducing seed-borne infections.

Table 2. Screening of plant species for antifungal activities

\begin{tabular}{lllll}
\hline Scientific name & Common name & Family name & Part used & Antifungal activity (mm) \\
\hline Allium sativum L. & Garlic & Liliaceae & Bulb (Fresh) & $10.83-24.33$ \\
Aloe vera L. & Aloe & Liliaceae & Leaves (Fresh) & - \\
Azadirachta indica A. Juss & Neem & Meliaceae & Seeds (Dry) & - \\
Carum carvi L. & Caraway & Apiaceae & Seeds (Dry) & - \\
Eucalyptus rostrata L. & Camphor & Myrtaceae & Leaves (Fresh) & - \\
Citrullus colocynthis L. & Bitter apple & Cucurbitaceae & Fruits (Dry) & 22.83 \\
Cuminum cyminum L. & Cumin & Apiaceae & Seeds (Dry) & - \\
Datura stramonium L. & Datura & Solanaceae & Leaves (Dry) & $12.33-20.83$ \\
Euphorbia peplis L. & Euphorbia & Euphorbiaceae & Leaves (Dry) & - \\
Jatropha curcas L. & Jatropha & Euphorbiaceae & Leaves and seeds (Dry) & - \\
Mentha piperita L. & Peppermint & Lamiaceae & Leaves (Fresh) & - \\
Musa acuminate L. & Banana & Musaceae & Leaves (Fresh) & - \\
Nigella sativa L. & Black seeds & Ranunculaceae & Seeds (Dry) & - \\
Ocimum basilicum L. & Basil & Lamiaceae & Leaves and seeds (Dry) & - \\
Rosmarinus officinalis L. & Rosmary & Lamiaceae & Leaves (Dry) & - \\
Zingiber officinale Rosc. & Ginger & Zingiberaceae & Rhizome (Dry) & $8.0-16.83$ \\
& & & & \\
\hline
\end{tabular}

- = no antifungal activity

These results are in agreement with the findings of [40] who found that garlic extract was superior in terms of reducing seed-borne infections by Alternaria spp., Bipolaris sorokiniana, Curvularia lunata and Fusarium spp. infecting wheat grains. Mondall et al. [41] 
reported that seed treated with the Garlic extract, reduced seed-borne prevalence and increased germination percentage of wheat seeds. In addition, aqueous extracts of Garlic bulb and ginger rhizomes were significantly exhibited antifungal activity against all tested fungi. These aqueous extracts were strongly inhibited seed infection.

The treated seeds and grains with the extracts of Datura showed very low infection by fungi rather than bitter apple. The effect of extracts depends on their concentrations. These results are in agreement with the findings of Reddy et al. [42]. They reported that the plant extracts completely inhibited A. flavus. Some important seed-borne pathogens like Fusarium oxysporum, Aspergillus niger, A. flavus, Penicillium spp. and $P$. vexans can be managed by using some plant extracts [43]. Exploitation of naturally available chemicals from plant protection would be a prominent role in development of future commercial pesticides for crop protection strategies, with special reference to manage plant diseases [44].

\section{Conclusion}

The study confirms that the natural plant extracts may be safer for human health than chemical fungicides to combat the fungi that cause deterioration of stored grains and seeds. The using of these extracts can also reduce wastage during storage process, as well as increasing seed germination during agriculture. Datura, bitter apple, garlic and ginger extracts are recommended as antifungal agents for preserving grains and seeds.

\section{References}

[1] J.B. Harborne, Phytochemistry of the Leguminosae .In: Bisby FA, Southon IW, editors. Phytochemical Dictionary of the Leguminosae. Boca Raton: Chapman and Hall. (1994)

[2] ILDIS, International Legume Database and Information Service, World Database of Legumes (version 9.00), Canberra, AUS. (2004)

[3] J.M. Awika, Major cereal grains production and use around the world. In: J.M.Awika; V. Piironen; S. Bean, editors. Advances Promotion in Cereal Science: Implications to Food Processing and Health. American Chemical
Society: Washington, DC, USA. (2011). pp. 113

[4] K. Kubiak and M.Korbas, Occurrence of fungal diseases on selected winter wheat cultivars. Postepy Ochronie Roslin 39 (1999) 801-804

[5] R.B. Weber; B.Hrynczuk; H .Runowska and B. Kita, Influence of the mode of tillage on diseases of culms base in some winter wheat varieties, oats, and spring wheat. J Phytopathol.149 (2001) 185-188

[6] C.R. Jackson, Small-plot evaluation of seed treatment fungicides for control of Aspergillus crown rot of peanut. Pl DIs. Reptr. 47 (1963) $147-150$

[7] K.K. Pal and B.M. Gardener, Biological Control of Plant Pathogens. The Plant Health Instructor DOI: 10.1094/PHI-A (2006) 1117

[8] A.B. Hashem, Antifungal properties of crude extracts of five Egyptian medicinal plants against dermatophytes and emerging fungi. Mycpathologia 172 (2011) 37-46

[9] M.Y. Yoon; G.J. Choi; Y.H. Choi; K.S. Jang; B. Cha and J.C .Kim, Antifungal activity of polyacetylenes isolated from Cirsium japonicum roots against various phytopathogenic fungi. Industrial crops and products, 34 (2011) 882-887

[10] M.I. Ammar; G.E. Nenaah and A.H. Mohamed, Antifungal activity of prenylated flavonoids isolated from Tephrosia apollinea L. against four phytopathogenic fungi. Crop Protect. 49 (2013) 21-25

[11] D.M.Nguyen; D.J.Seo; H.B.Lee; I.S.Kim; K.Y.Kim; R.D.Park and W.J. Jung, Antifungal activity of gallic acid purified from Terminalia nigrovenulosa bark against Fusarium solani. Microbial Pathogenesis 56 (2013) 8-15

[12] M.N. Suleiman, Root rots disease of Cowpea (Vigna unguiculata) and its control using plant extracts and fungicides LAP Lamber Acd. Publishing, Germany, pp: 169. (2011)

[13] K.B. Raper and C. Thom, A Manual of The Pencillium. Hafiner Publish. Co., New York (1968)

[14] C. Booth, The Genus Fusarium. Common wealth Mycological Institute, Kew, Surrey, England. Pp 237. (1971)

[15] M.B. Ellis, Dematiaceous Hypomycetes. Cab International, Kew, Surrey, England. Pp 608. (1971)

[16] K.B. Raper and D.I. Fennell, The genus Aspergillus. Robert EK Publish.Co., Huntington, New York, USA. (1977)

[17] C.J. Alexopoulus and C.W. Mims, Introductory Mycology. The $3^{\text {rd }}$ ed., Willey Eastern Limited, India, pp. 632. (1988)

[18] H.L. Barnet and B.B. Hunter, Illustrated Genera of Imperfect Fungi ( $3^{\text {rd }}$ ed.), Burgess Publishing Company, Minnesota, USA, pp 24. (1994)

[19] A.F. Mostafa Zygomycetes, Fungi of Egypt AUMC descriptions, No.1.Assuit University 
Mycological Center (AUMC), Assiut, Egypt (2006)

[20] B.F.A. Dababneh and K.S. Al-Delaimy, Inhibition of Saphylococcus aureus by garlic extract. Lebensm Wiss Technol., 17 (1984) 2931

[21] I.A.Gurgel; J.J.Sidrim; D.T. Martins; V. Cechinel Filho and V.S. Rao, In vitro antifungal activity of dragon's blood from Croton urocurana against dermophytes. J Ethnopharmacol 97 (2005) 409-412

[22] S.B. Mathur and O. Kongsdal, Common Laboratory Seed Health Testing Methods for Detecting Fungi. Kandrup Bogtrykkeri, Arhusgade 88, DK - 2100 Copenhagen, Denmark (2003)

[23] C.Diaz; M. Hossain; M.L.Bose; S. Mercea and T.W. Mew, Seed quality and effect on rice yield: findings from farmers participatory experiment in Central Luzon, Philippines. J. Crop. Sci., 23 (1998) 111-119

[24] B.K .Vaidehi, Seed mycoflora of sunflower - a perspective. Frontiers in Micro Biotech Plant Pathol 23 (2002) 25-40

[25] E.E. Stinson; D.D. Billis; S.F. Osman; J. Sciliano; M.J. Ceponis and E.G. Heisler, Mycotoxin production by Alternaria species grown on apples, tomatoes and blueberries. Agric Food Chem. 28 (1980) 960-963

[26] A.C. Shukla, Fungitoxic studies of some aromatic plants against storage fungi. $\mathrm{PhD}$ Thesis, University of Allahabad, Allahabad, India (1997)

[27] A.C. Shukla; S.K. Shahi; A .Dikshit, Epicarp of Citrus sinensis: A potential source of natural pesticide. Indian Phytopathol 53 (2000) 318-322

[28] R.K. Pandey, Physiological and Pathological Studies of Certain Fungi. Ph.D. Thesis, University of Allahabad, Allahabad, India (2008)

[29] A.C .Shukla, Bioactivities of the major active constituents isolated from the essential oil of Cymbopogon flexuosus (Steud.) Wats and Trachyspermum ammi (L) Sprague as a herbal grain protectant(s).D.Sc. Thesis, Allahabad University, India (2010)

[30] R.A. Samson; E.S. Hoekstra; J.C. Frisvad and O .Filterborg, Introduction to food borne fungi. Ponsen and Looyen Publishers, Wageningen, The Netherlands (1995)

[31] E .Shaaya, M .Kostjukvshi, J .Eilberg and C. Sukprakaran, Plant oils as fumigants and contact insecticides for the control of stored product insects. Journal of Stored-Product Research, UK, 7-15. 33 (1997) 7-15

[32] D.K.Jka; G.D.Sharma; R.R. Mishra, Ecology of soil microflora and mycorrihzal symbionts in degraded forests at two altitudes. Biology and Fertility of Soils 12 (1992) 272-278

[33] L.D. Lawson, Garlic: a review of its medicinal effects and indicated active compounds. In: D. Lawson; R. Bauer editors. Phytomedicines of Europe: Chemistry and Biological Activity, ACS symposium series 691, American Chemical Society,Washington, DC. pp. 176-209 (1998)

[34] H.Matsuura; T.Ushiroguchi; Y.Itakura; H. Hayashi and T.I. Fuwa, A furostanol glycoside from garlic bulbs of Allium sativum .Chemical and Pharmaceutical Bulletin 36 (1988) 36593663

[35] A. Rajesh and G.L. Sharma, Studies on antimycotic properties of Datura metel. Journal of Ethnopharmacology 80 (2002) 193-197

[36] P. Koushik and P. Goyal, In vitro evaluation of Datura innoxia (thorn-apple) for potential antibacterial activity. Indian Journal of Microbiology 48 (2008) 353-357

[37] I. Hussain; M.A. Nasir and M.R. Haque, Effect of different plant extract on brown rust and yield of wheat. Agriculture Research 30 (1992) 127131

[38] C. Ficker; M. L.Smith; K.Akpagana; M. Gbeassor; J. Zhang; T. Durst; A. Assabgui and J.T. Arnason, Bioassay-guided isolation and identification of antifungal compounds from ginger. Phototherapy Research 17 (2003) 897902

[39] H.R. Anthony, Chemical Microbiology, An Introduction to Microbial Physiology $\left(3^{\text {rd }}\right.$ ed). Butterworth and Co. (Publishers) Ltd, London, UK. (1976)

[40] ISTA, International Rules for Seed Testing Association. Int. Seed Test Assoc. 31: 107115.Jakso 463. (1976)

[41] N.K. Mondall; A.S.K Mojumdar; A.Chatterje; J.K. Banerjee and S. Gupta, Antifungal activities and chemical characterization of neem leaf extracts on the growth of some selected fungal species in vitro culture medium. Journal of Applied Sciences and Environmental Management 13 (2009) 49-53

[42] C.S. Reddy; K.R. N. Reddy; M. Prameela; U. N. Mangala and K. Muralidharan, Identification of antifungal component in clove that inhibits Aspergillus sp. colonizing rice grains. J. Mycol. Plant Pathol. 37 (2007) 87-94

[43] H. El-Fadaly, Efficacy of certain plant extracts on some phytopathogenic fungi. Proc.the $9^{\text {th }}$ Conf. Microbiology, Cairo, 25-27 March,241257. (1977)

[44] J. Verma and N.K .Dubey, Prospective of botanicals and microbial products as pesticides of tomorrow. Current Science 76 (1999) 172-179 
الملخص العربى

تقييم بعض المستخلصات النباتية لمقاومة الفلورا الفطرية المسببة لفساد الحبوب والبقوليات المخزنة

$$
\begin{aligned}
& \text { زكريا عوض محمد بقا، ممدوح سالم سراج، طارق عبد الرازق كردوشه }
\end{aligned}
$$

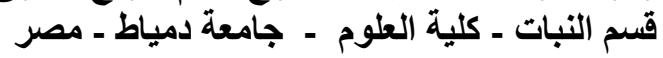

تهدف الدراسة إلى عزل وتعريف بعض الفطريات المسبية لفساد بعض الحبوب والبقوليات واستخدام

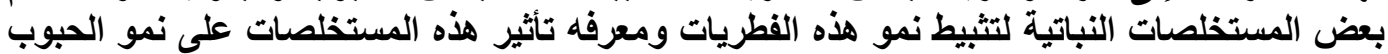

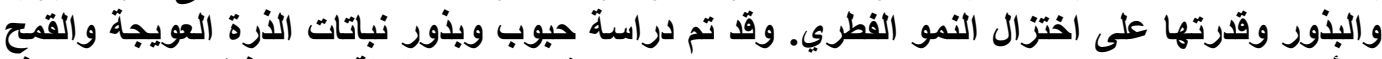

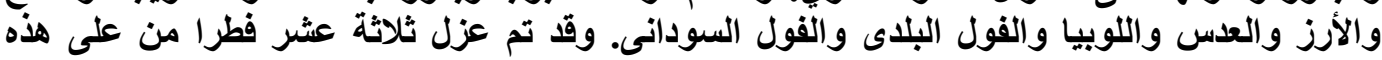

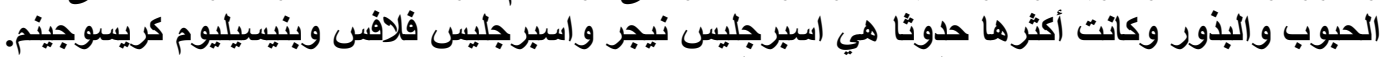

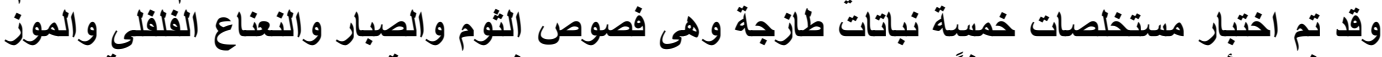

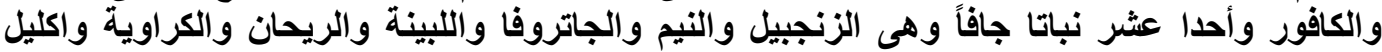

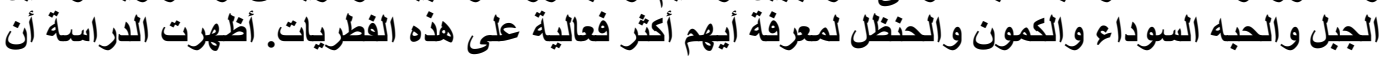

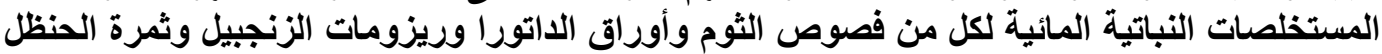

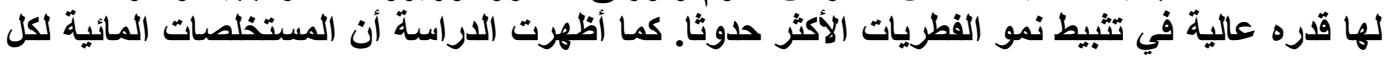

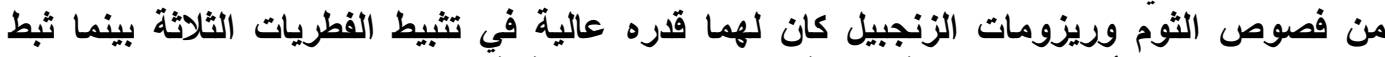

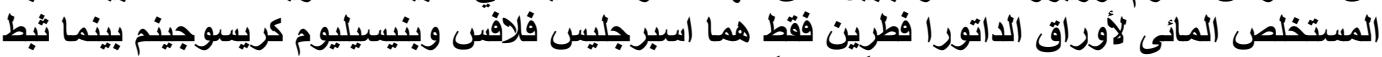

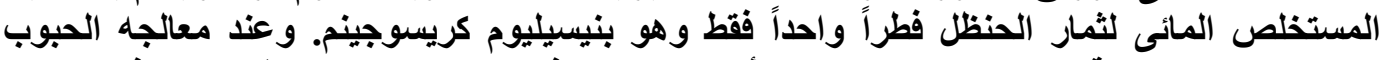

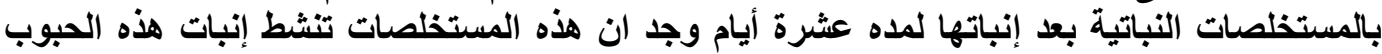

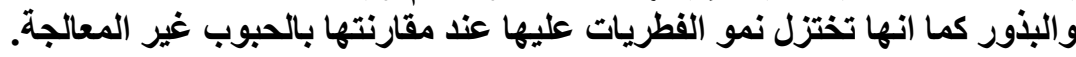

